\title{
Teatro e microutopias cotidianas: experiências de comunidade no espetáculo no mundo da rua
}

Saulo Vinicius Almeida ${ }^{1}$

Recebido em: 07/07/2019

Aprovado em: 06/11/2019

DOI: $10.5965 / 2358092521222019081$

${ }^{1}$ Bacharel em Teatro pela UFRGS, mestrando em Artes Cênicas pela USP. Ator e diretor teatral. E-mail: sauloalmeida@usp.br 


\section{RESUMO}

A partir do conceito Viver-Junto-idiorrítmico de Roland Barthes e abrindo diálogo com o conceito de Heterotopia de Michel Foucault e as análises acerca da Arte Relacional de Nicolas Bourriaud, serão apresentadas algumas características presentes no pensamento artístico das últimas décadas, o qual nós compreenderemos aqui sob o conceito de pós-moderno. Tal discussão será a base para análise do espetáculo No Mundo da Rua, do coletivo paraibano Projeto Corpos de Saia e de sua relação com os espaços urbanos e as experiências de comunidade. A conclusão atesta que para além de propor uma breve experiência de outra possível realidade, o Viver-Junto-idiorrítmico pode desvelar, a partir da iluminação das narrativas sociais, as quais são potencializadas pela presença e performatividade de corpos com marcadores sociais da diferença, a ficcionalidade da vida vivida.

Palavras-chave: Viver-Junto-idiorrítmico. Arte Relacional. Pós-modernismo. Performance.

\section{ABSTRACT}

Based on Roland Barthes' Living-Together-Idiorhythmic concept and opening a dialogue with Michel Foucault's concept of Heterotopia and Nicolas Bourriaud's analyzes of Relational Art, we will introduce some characteristics present in the artistic thought of the last decades, which we will understand here under the concept of post-modern. Such discussion will be the basis for the analysis of the performance No Mundo da Rua, made by the Projeto Corpos de Saia paraibano collective, and its relationship with urban spaces and community experiences. The conclusion attests that in beyond to proposing a brief experience of another possible reality, Living-Together-Idiorhythmic can unveil, from the illumination of social narratives, which are enhanced by the presence and perfor- 
mativity of bodies with social markers of difference, the fictionality of lived life.

Keywords: Living-Together-Idiorhythmic. Relational Art. Post-Modernism. Performance.

\section{A ARTE PÓS-MODERNA NA DIMENSÃO DAS MICROUTOPIAS COTIDIANAS}

O imaginário moderno que se configurou como uma desqualificação do passado em prol de um futuro, estruturando-se por posições conflitantes deu lugar a um imaginário preocupado com negociações, com estabelecimento de vínculos e com a coexistência de contradições. Parte das experiências teatrais contemporâneas abandona a construção formal que visa traçar análises sociais e apontar possíveis transformações sociais tendo em vista um futuro utópico e de certa forma mítico para construir espaços concretos de relação e negociação, experiências de comunidade, como na obra The Artist is Present de Marina Abramovic ou na Intervenção Dalloway: Rio dos Malefícios do Diabo do Grupo XIX. Andreas Huyssen (1992) analisa que as teorias pós-estruturalistas liberaram a arte da sobrecarga de responsabilidades que recaia sobre a mesma devido à pretensão de uma mudança total da sociedade. Tal anseio teria, segundo o autor, levado a vanguarda histórica ao naufrágio. Ricardo Fabbrini (2018) destaca que noções como heterotopia e a ideia de comunidade têm sido mobilizadas pelos críticos de arte para pensar essas tentativas artísticas de imaginar outros mundos possíveis ao mesmo tempo em que vivenciam sua concretização efêmera. Na perspectiva de Rancière (2010, p. 18), a ideia de comunidade que instaura-se "sobre a ruína das perspectivas de emancipação política com as quais a arte moderna se vinculou é uma comunidade ética que revoga todo projeto de emancipação coletiva". 
Tratarei aqui, portanto, de um pensamento teatral que se constrói dentro da ideia de construções efêmeras de comunidades que visam instaurar espaços outros dentro da realidade concreta, criando, a partir de uma experiência estética, relações de estranhamento dos sujeitos envolvidos no ato cênico com a forma de vida imposta pelo nosso tempo. Ao contrário das vanguardas, nas quais havia o desejo de criarem-se novos mundos a partir de novas relações, parte da produção artística contemporânea aposta na criação de novas relações com o mundo já existente (FABBRINI, 2016). Tratarei de uma fantasia de vida, de gênero de vida, de outras possibilidades de ocupar o mesmo espaço-tempo que não aquelas mediadas pelo desejo de se estabelecer domínio ou controle uns sobre os outros e que não se dão a partir de um projeto de emancipação coletiva. A partir do conceito Viver-Junto-idiorrítmico de Roland Barthes e abrindo diálogo com o conceito de Heterotopia de Michel Foucault e as análises acerca da Arte Relacional de Nicolas Bourriaud, apresentarei algumas características presentes no pensamento artístico das últimas décadas, o qual nós compreenderemos aqui sob a égide do pós-modernismo. Tal discussão será a base para análise do espetáculo No Mundo da Rua do coletivo paraibano Projeto Corpos de Saia.

Roland Barthes (2003) em seu curso Como viver junto: simulações romanescas de alguns espaços cotidianos mergulha na fantasmática do Viver-Junto, da tensão limite entre o desejo de se viver só e de viver junto a outros. Trata-se da "utopia de um socialismo das distâncias", de uma solidão que é interrompida de modo regrado. Esse desejo barthesiano, ou essa fantasia do Viver-Junto atravessou em diversas escalas outras pessoas no decorrer da história, tais como, Saint-Simon (1760-1825), Charles Fourier (1772-1837) e Robert Owené (1771-1858). Pensadores aos quais hoje damos o título de socialistas utópicos, cada qual apresentando uma possível imagem desta fantasmática. É precisamente ao Falanstério de Fourier que Barthes dirige-se inicialmente e brevemente (enfatizando que não trataria deste) para principiar o compartilhamento com o leitor do que seria seu desejo do Viver-Junto. 
"As Falanges propostas por Fourier seriam correspondentes a pequenas unidades sociais com populações de cerca de 1500 habitantes, e cada uma possuiria um edifício comum chamado Falanstério no qual todos viveriam harmoniosamente" (BARROS, 2011, p. 246). A fantasia em Fourier, na ótica de Barthes (2003), parte de um "gosto de estar só" (p. 9). No Falanstério, contradições "seriam reconhecidas (e portanto restringidos os riscos de impostura ideológica)", de modo que "a diferença seria observada e o conflito acometido de insignificância (sendo improdutor de prazer)" (BARTHES, 1987, p. 23). É também nos conventos cenobíticos que o autor enxerga a coexistência do exercício de solidão e de compartilhamento do espaço, "monges ao mesmo tempo isolados e religados no interior de certa estrutura" (BARTHES, 2003, p. 13). A proposta de Barthes, embora apresente convergências, busca superar estes exemplos, pois para ele, "elas [essas grandes formas, falanstério e conventos cenobíticos] são estruturadas segundo uma arquitetura de poder" antipáticas à idiorritmia. Estruturas as quais a sua ideia de comunidade aboliria. $\mathrm{O}$ autor também verifica enquanto ponto negativo, "uma inumanidade profunda no Falanstério de Fourier" (BARTHES, 2003, p. 18).

Nesta fantasia barthesiana está colocado um ataque a certo tipo de submissão a qual o sujeito é exposto no cotidiano social. Tal submissão ocorre em função da imposição de formas de vida que impelem, deste modo, determinados ritmos aos indivíduos. O sujeito "que abolisse nele as barreiras, as classes, as exclusões, não por sincretismo, mas por simples remoção desse velho espectro: a contradição lógica" (BARTHES, 1987, p. 7), que sustentasse em toda sua inteireza o ilogismo, fruto de certa unidade do ser, da individuação, "seria a abjeção de nossa sociedade: os tribunais, a escola, o asilo, a conversação, convertê-lo-iam em um estrangeiro: quem suporta sem nenhuma vergonha a contradição?" (BARTHES, 1987, p. 7).

Em uma sociedade que é regulada pela divisão de trabalho, por uma superespecialização, pela mecanização humana e pela lei do lucro importa "aos governantes [...] tanto que as relações humanas sejam canalizadas para vias de saídas projetadas para 
essa finalidade quanto que elas se processem segundo alguns princípios simples, controláveis e repetíveis" (BOURRIAUD, 2009, p. 12) impelindo aos indivíduos deste modo, formas de ser, estar e se relacionar.

A proposta de comunidade de Barthes, sob o título de Viver-Junto, exige certa disritmia, certo descompasso entre o ritmo dos indivíduos que coabitam determinado espaço-tempo, exige uma contraposição às formas de vida impostas, pois nela, "cada sujeito tem seu ritmo próprio" (BARTHES, 2003, p. 13). A palavra ritmo no sentido colocado pelo autor diz respeito ao sentido da palavra grega rhythmós enquanto "modelo de um elemento fluído", "forma improvisada, modificável" (BARTHES, 2003, p. 15). O "rhythmós é, por definição, individual: interstícios, fugitividade do código, do modo como o sujeito se insere no código social (ou natural)" (BARTHES, 2003, p. 16).

O ritmo diz respeito ao aprofundamento do sujeito em seu processo de individuação, às suas configurações não estáveis, às alternâncias entre as polaridades do humor - da depressão à mania, por exemplo. É o ato de existir livre do ritmo imposto massivamente à sociedade. É uma proposta de encontro em que "a diferença se insinue sub-repticiamente no lugar do conflito" (BARTHES, 1987, p. 23). A idiorritimia é uma convivência na qual os ritmos individuais sobreviveriam ao encontro, na qual a solidão e a integração aconteceriam conjuntamente. Para caracterizar o problema da idiorritimia, Barthes (2003, p. 19) utiliza o exemplo que transcrevo abaixo:

De minha janela ( $1^{\circ}$ de dezembro de 1976$)$, vejo uma mãe segurando o filho pequeno pela mão e empurrando o carrinho vazio à sua frente. Ela ia imperturbavelmente em seu passo, o garoto era puxado, sacudido, obrigado a correr o tempo todo, como um animal ou uma vítima sadiana chicoteada. Ela vai em seu ritmo, sem saber que o ritmo do garoto é outro. E, no entanto, é a sua mãe!

A partir deste exemplo de Barthes, podemos verificar que o poder é exercido nas relações heterorrítmicas. Certamente, a proposta de um Viver-Junto-idiorrítmico não anula as opres- 
sões estruturais do sistema em que vivemos e nem ao menos se propõe a tal, abdicando a qualquer imaginário utópico de profunda transformação social, mas traça outras possibilidades na dimensão dos pequenos encontros, nas relações interpessoais, gerando deste modo, novas formas de ação ou outros modos de existir. A proposta barthesiana é um traçar linhas de fuga individuais ou coletivas destas arquiteturas de poder. Diz Barthes (2003, p. 256): “Quanto a mim, lamentei sempre que não houvesse uma utopia doméstica, e tive muitas vezes vontade de a escrever: um modo ideal (feliz) de figurar, de predizer a boa relação do sujeito com o afeto, com o símbolo. Ora, isso não é propriamente uma utopia".

Com o afastamento do ideal moderno de transformação total da sociedade e da perspectiva de que o embaralhamento entre arte e vida levaria à emancipação, artistas buscam dispositivos que possibilitem estabelecer zonas de relação dentro da realidade existente. Nicolas Bourriaud (2009, p. 18) em seu texto Arte Relacional, publicado no final do século XX, no qual buscou entender as obras de arte realizadas no decorrer da década de 1990, diz: "as obras já não perseguem a meta de formar realidades imaginárias ou utópicas, mas procuram constituir modos de existência ou modelos de ação dentro da realidade existente, qualquer que seja a escala escolhida pelo artista". A utopia doméstica figura na compreensão da incapacidade de transformação social, de modo a estabelecer pequenas comunidades éticas.

Barthes (2003) pensa esta utopia doméstica na chave do habitar. Esse desejo é apenas "a busca figurativa do Soberano Bem. Aqui: o Soberano Bem quanto ao habitar. Ora, O Soberano Bem - sua figuração - mobiliza toda a extensão e a profundidade do sujeito, em sua individuação, isto é, em sua história pessoal, completa" (BARTHES, 2003, p. 256). Neste anseio de Barthes, o sujeito é colocado em evidência em detrimento do coletivo. Sua história pessoal e sua postura ética, sua relação afetiva são colocadas como foco ao invés das estruturas econômicas e histórico-sociais que encontram-se por detrás das atitudes dos indivíduos e grupos. 
Diante disto, podemos dizer que em Nicolas Bourriaud encontra-se a mesma conclusão acerca da relação entre utopia e sociedade contemporânea. O autor, tecendo análises a partir da arte relacional, a qual também pode ser lida na chave do habitar, problematiza a questão da arte em conexão com utopias sociais e com a esperança revolucionária. Nisto, aproxima-se da noção de utopia doméstica barthesiana. Para o autor, as utopias sociais e a esperança revolucionária "deram lugar a microutopias cotidianas e a estratégias miméticas: qualquer posição 'crítica' direta contra a sociedade é inútil, se baseada na ilusão de uma marginalidade hoje impossível, até mesmo reacionária" (BOURRIAUD, 2009, p. 44).

A arte moderna dos manifestos futurizantes, da predição de um novo homem, a arte vanguardista teria passado dando lugar às experiências na qual se vive a utopia do cotidiano subjetivo. A partir de experimentações concretas tecem-se possibilidades de vida no âmago da realidade, buscam-se margens e experiências completamente outras, experiências que rasguem, gerem fissuras na normalidade imposta como padrão de conduta e convívio (BOURRIAUD, 2009).

Se formos buscar certa relação entre esse espaço fundado a partir das relações de um Viver-Junto-idiorrítmico e a heterotopia foucaultiana. Foucault (2013) entendendo as utopias como algo que possui um lugar preciso e real e um "tempo que podemos fixar e medir conforme o calendário de todos os dias" (FOUCAULT, 2013, p. 19) propõe a noção de heterotopia. Tal conceito diz respeito a lugares completamente outros, a uma justaposição de um lugar real e "vários espaços que, normalmente, seriam ou deveriam ser incompatíveis" (FOUCAULT, 2013, p. 24). A heterotopia é uma construção que se coloca em contestação ou atrito com os outros espaços, a partir de uma heterotopia se denuncia todo o resto da realidade, tornando evidente pela comparação, as falhas, os desarranjos dos espaços instituídos na realidade.

O Viver-Junto-idiorrítmico caso instaurado, plasmaria outro espaço dentro da realidade, uma heterotopia. O contrário, porém, não é de todo verdadeiro. A heterotopia propõe o deslo- 
camento do espaço estabelecido, mas não solicita outra atitude dos sujeitos. Para que se instaure uma heterotopia não é necessário que haja o respeito ao ritmo individual e nem ao menos que se criem distâncias limites que mantenham o indivíduo em solidão e em coletivo simultaneamente. Não há na fantasia foucaultiana a ficção de certa docilidade por parte dos presentes. Foucault (2013) pensa sua teoria a partir da análise de espaços presentes, de certa forma, no cotidiano como, o jardim atrás da casa ou a grande cama onde as crianças podem nadar entre as cobertas em um exercício lúdico; ou que estiveram presentes ao longo da história, como os lugares sagrados ou proibidos das sociedades arcaicas, as casas de repouso, clínicas psiquiátricas, o cemitério, o teatro e, aquele que é uma heterotopia por excelência, o navio. "O navio é um pedaço, lugar sem lugar, com vida própria, fechado em si, livre em certo sentido, mas fatalmente ligado ao infinito do mar" (FOUCAULT, 2013, p. 30). Já em Barthes (2003, p. 257), "somente uma escritura poderia dar conta - ou então um ato romanesco (se não um romance)" de seu desejo, de sua fantasmagoria.

“O texto não é nunca um 'diálogo': não há risco nenhum de fingimento, de agressão, de chantagem, nenhuma rivalidade de idioletos; ele institui no seio da relação humana - corrente uma espécie de ilhota" (BARTHES, 1987, p. 24). Além disto, "os romances são simulações, experimentações fictícias sobre um modelo, do qual o mais clássico é a maquete" (BARTHES, 2003, p. 25). Seria possível estabelecer o Viver-Junto-idiorrítmico como uma forma de ação, de intervenção - ainda que temporária - no tecido da realidade? Faz-se mister perceber que qualquer ação de compartilhamento de espaços, qualquer ação de convivência necessita ocorrer em um encontro no qual não haja o intuito de transmitir uma ideia, que não haja o movimento de colonização do outro, da ação coercitiva. O Viver-Junto-idiorrítmico deve se estabelecer no desejo do contato, da troca, abdicando desta maneira de qualquer estabelecimento de controle ou domínio sobre aquele que ouve ou vê. Os ritmos próprios devem ser respeitados e mantidos de acordo com o desejo de cada sujeito. 
Seria possível, dentro dessas premissas, compreender o ato teatral que se constrói a partir do conceito de Arte Relacional ou da Cena Expandida como um Viver-Junto-idiorrítmico? Encontramos em Barthes (1987) uma crítica a certo tipo de teatro, especificamente ao papel do espectador que o autor compreende como passivo, ao contrário do que, para ele, ocorre no texto escrito: “Na cena do texto não há ribalta: não existe por trás do texto ninguém ativo (o escritor) e diante dele ninguém passivo (o leitor)" (BARTHES, 1987, p. 24); e citando Angelus Silesius, diz: "O olho por onde vejo Deus é o mesmo olho por onde ele me vê" (BARTHES, 1987, p. 25). Para que tal coisa seja possível no teatro é necessário que se conceba o espectador conforme Jacques Rancière (2012), ou seja, um espectador emancipado que "deve ser retirado da posição de observador que examina calmamente o espetáculo que lhe é oferecido"; um espectador que seja "desapossado desse controle ilusório, arrastado para o círculo mágico da ação teatral, onde trocará o privilégio de observador racional pelo do ser na posse de suas energias vitais integrais" (RANCIÈRE, 2012, p. 10). Apenas desta forma seria possível começar a se pensar em um encontro teatral no qual o ritmo pessoal dos que ali se encontram no papel de público seja respeitado.

\section{NO MUNDO DA RUA - EXPERIÊNCIAS IDIOR- RÍTMICAS NA PARAIIBA}

Estou aqui oferecendo o meu corpo para pessoas que querem fazer massagens outras e não têm em quem fazer. Para cada massagem, eu ofereço uma poesia. Mas, essa poesia vai depender da forma que a massagem for feita. A massagem tensa e forte causa uma poesia tensa e forte (Trecho da peça No Mundo da Rua do Projeto Corpos de Saia).

Tomarei por objeto de análise o espetáculo teatral paraibano No Mundo da Rua, cuja encenação é assinada por Sávio Farias $^{2}$. Como o próprio nome sugere, a peça se passa em espaços

2 Doutorando e Mestre em Artes Cênicas pela Universidade Federal da Bahia; Bacharel e Licenciado em Teatro pela Universidade Federal da Paraíba. Integran- 
públicos, praças, ruas de bares, estações de trem. Esse primeiro dado é relevante na medida em que compreendemos que o edifício teatral, embora seja compreendido por Foucault como uma heterotopia, coloca-se na contramão do que poderia vir a ser um espaço idiorrítmico. O edifício teatral impõe aos corpos que ali permanecerão um ritmo específico durante o tempo do espetáculo. O público assim se faz naquele espaço não apenas pela sua função de ver, mas também por uma série de atitudes e gestos que aquele espaço exige do mesmo. Além disto, podemos encarar tal edifício como um dos espaços mercantis de que nos fala Bourriaud (2009, p. 12), o que o coloca dentro da lógica das estruturas de poder. Para escapar do domínio do previsível que esses espaços nos impõem, "a relação humana - simbolizada ou substituída por mercadorias, sinalizada por logomarcas precisa assumir formas extremas ou clandestinas, uma vez que o vínculo social se tornou um produto padronizado".

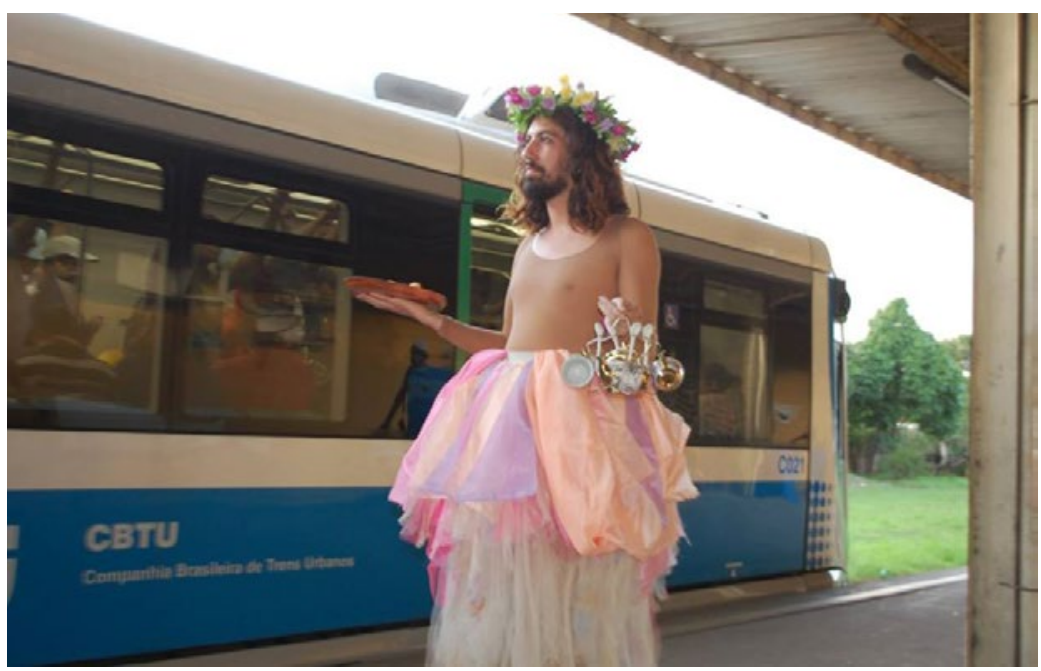

Figura 1: Apresentação na estação de trem

Fonte: Acervo do Projeto Corpos de Saia

te-fundador do Grupo Bufões de Olavo e do Projeto Corpos de Saia, desempenhando em ambos funções alternadas de atuação, dramaturgia, encenação e produção. 
Não que o espetáculo de rua necessariamente não imponha um ritmo, uma forma de ser aos presentes, mas na medida em que se estrutura como possibilidade de espaço de passagem no qual os sujeitos possuem a facilidade de decidir permanecer ou continuar a sua caminhada sem que para tal, ele tenha que passar por portas, seguranças e salas escuras, a rua dá autonomia ao público. A rua, para Bourriaud (2009), em contraposição aos espaços aristocráticos de arte, instaura um "regime de encontro casual intensivo". A utilização do espaço urbano, no decorrer da década de 1990, gerou uma "forma de arte cujo substrato é dado pela intersubjetividade e tem como tema central o estar juntos, o 'encontro' entre observador e quadro, a elaboração coletiva do sentido" (BOURRIAUD, 2009, p. 21).

A utilização da rua por artistas se tornou pauta de disputa política nos últimos anos no Brasil. Inúmeros governos municipais têm tentado proibir os artistas de ocuparem as ruas e de apresentar nessas o seu trabalho. A prefeitura de Belo Horizonte nos últimos anos tem utilizado de dispositivos legais para dificultar e/ou proibir a apresentação de artistas de rua, além de proibir o que compreende como manifestações políticas durante eventos de grande porte, a exemplo da Virada Cultural de Belo Horizonte em 2016 (AMARAL; MELLO, 2016). A prefeitura de Porto Alegre constantemente tenta, do mesmo modo, proibir o trabalho artístico em ruas e praças (FOGLIATTO, 2015). Frequentemente temos sido surpreendidos com notícias de censuras realizadas contra artistas, como ocorreu nos recentes casos da peça Blitz - O Império nunca dorme, na cidade de Santos - SP, e com a dança instalação DNA de DAN do artista curitibano Maikon K, que foi agredido pela Polícia Militar (PM) e preso em meio a uma apresentação.

Levando em consideração a assertiva de Rancière (2010, p. 20):

A arte não é política em primeiro lugar pelas mensagens e pelos sentimentos que transmite sobre a ordem do mundo. Ela também não é política pelo seu modo de representar as estruturas da sociedade, os conflitos ou as identidades dos grupos sociais. 
[Ela se faz] política pela distância que toma em relação a essas funções, pelo tipo de tempo e de espaço que institui, pelo modo como recorta esse tempo e povoa esse espaço.

É relevante notar que no caso da obra DNA de DAN, a censura (em sua forma mais violenta) não se deu em função de um possível discurso crítico a um governo ou a um órgão de poder, mas sim em função da instauração de outra relação do corpo com o espaço público, que não a cotidiana e normatizada e dos desdobramentos que essa relação gerou ou possui o potencial de gerar. É a intervenção concreta no tecido da realidade que foi censurada e não a crítica.

A estratégia utilizada pelo grupo de artistas paraibanos na elaboração da obra No Mundo da Rua e da transformação do espaço público cotidiano nesse espaço outro, nesse território em que se faz temporalmente presente a comunidade, se inicia pelos afetos dóceis. O desejo barthesiano desse "Soberano Bem" na dimensão do habitar se faz presente pela docilidade e por certa fragilidade no encontro inicial entre artistas e demais presentes.

As palavras ditas nascem das relações entre sujeitos atuantes ou performers e o público. A relação entre eles torna-se texto espetacular, de modo que o público transita entre a prática contemplativa e a reação e interação com a obra. Há nisto uma elaboração coletiva dos sentidos, uma tentativa de exercício democrático, em certa medida, da arte. Os performers adentram aos poucos no espaço que se tornará, posteriormente, o espaço cênico. Seja esse espaço, um bar, uma estação de trem ou a rua propriamente dita, e buscam realizar trocas de produtos ou serviços com as pessoas que ali estão. A troca que propõem pode ser de uma massagem por um poema (como no trecho anteriormente citado), de um pirulito no formato de coração por um sorriso, por um abraço ou pelo que as pessoas quiserem oferecer, desde que seja uma troca de amor por amor. 


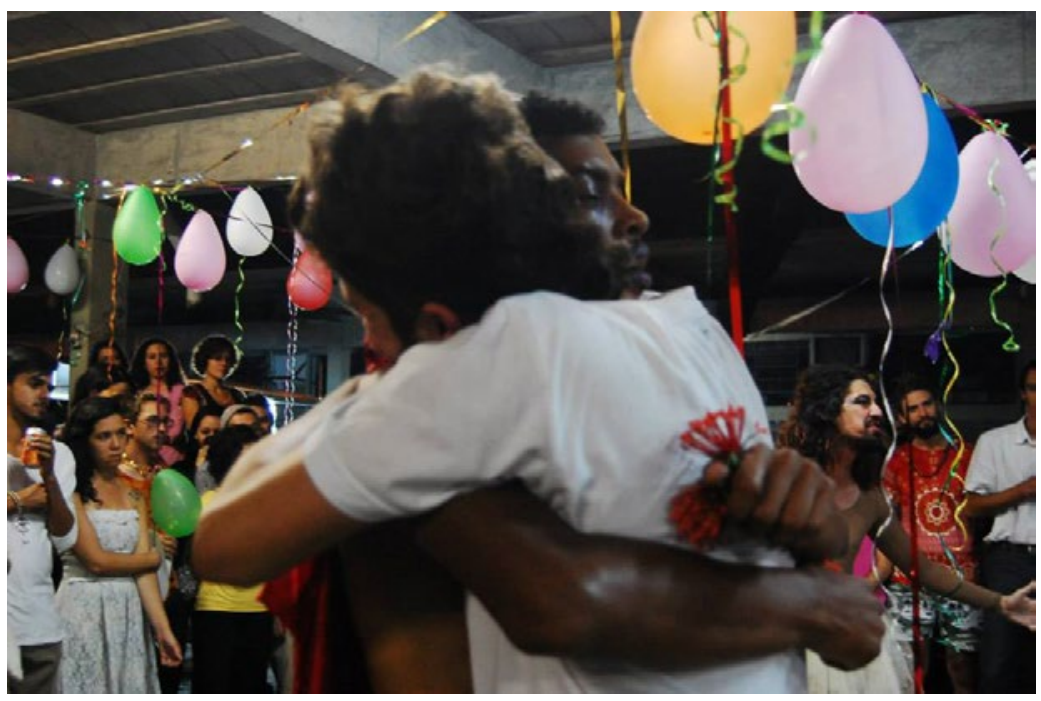

Figura 2: Interstício

Fonte: Acervo Projeto Corpos de Saia

Bourriaud (2009) chama a atenção para a obra de arte contemporânea representar um interstício social. Interstício é um termo empregado por Karl Marx para nomear comunidades de troca que, por não obedecerem à lei do lucro, fugiam do quadro da economia capitalista. Sendo ele, o interstício, "um espaço de relações humanas que mesmo inserido de maneira mais ou menos aberta e harmoniosa no sistema global, sugere outras possibilidades de troca além das vigentes nesse sistema" (BOURRIAUD, 2009, p. 22-23). Para o autor, seria exatamente esta

a natureza da exposição de arte contemporânea no campo do comércio das representações: ela cria espaços livres, gera durações com um ritmo contrário ao das durações que ordenam a vida cotidiana, favorece um intercâmbio humano diferente das zonas de comunicação que são impostas (BOURRIAUD, 2009, p. 23). 
Nesta espécie de simulação idiorrítmica não há a mediação de personagens na relação entre ator e aqueles que ali se encontram para ver ou que por ali passam e permanecem, ainda que por instante, relacionando-se de alguma forma com o acontecimento performático. O que há é uma imagem poética gerada no exercício de extrema exposição sincera de si. Aliás, a imagem não se forma apenas a partir desta exposição, mas na relação entre a exposição do performer e o corpo desejante do espectador que por vezes mergulha em memórias e por outras constrói fantasias. A forma, para Bourriaud (2009, p. 30), "é apenas uma propriedade relacional que nos liga aos que nos reificam pelo olhar. [..] a forma só assume sua consistência (e adquire uma existência real) quando coloca em jogo interações humanas". Essa lógica relacional a partir da qual o público está inserido no processo de produção da obra gerando formas e colaborando com o artista na elaboração do sentido é de certa maneira uma resposta dos artistas desde a década de 1990 à popularização da internet e sua lógica de redes, assim como às práticas coletivistas como as do universo da música tecno (BOURRIAUD, 2009).

Há nesta obra performática ao menos duas dimensões discursivas e relacionais que propõem experiências distintas, as quais eu chamarei aqui de experiência positiva do Viver-Junto-idiorrítmico e experiência negativa do Viver-Junto-idiorrítmico. O público é colocado desde o início não como um olhar, seja este olhar passivo ou ativo, mas como um corpo presente que carrega sua história, seus desejos e afetos, o seu ritmo próprio - como na fantasmática barthesiana. A presença, a gestualidade e as atitudes do público tornam-se parte da obra, sendo convertidas em forma e deste modo, estruturando ou apontando modelos de socialidade.

A experiência positiva do Viver-Junto-idiorrítmico se dá a partir da instauração de um sentimento de empatia e da sensação de pertencimento àquela comunidade formada. Nesta experiência, as individualidades são respeitadas e muitas vezes exploradas pelos sujeitos, e a sensação constante de crise que percorre a experiência da vida vivida é substituída pela ficção 
de uma zona temporária pacificada, dócil e reconciliada socialmente. Fabbrini (2018, p. 119) chama a atenção para o fato de que essa experiência de comunidade proposta por Barthes se daria de forma que cada "relação seria furta-cor, pois mudaria sutilmente de aspecto, talvez de sentido, ou de configuração, segundo a inclinação do olhar de cada membro".

A eficácia desta experiência estaria no estranhamento gerado quando o sujeito retorna às regras e funcionamentos da vida concreta, quando desse por fim a experiência heterotópica. "Jean Galard conjectura se estas práticas colaborativas não constituiriam um arremedo de reconciliação social, como se o estado do mundo pudesse ser retificado com um pouco de boa vontade e alguns louváveis exemplos" (FABBRINI, 2014, p. 11).

$O$ que entendemos aqui como a experiência negativa do Viver-Junto-idiorrítmico diz respeito ao que Barthes (2003) denominou de contra-imagens ou fantasias negativas do Viver Junto. As contra-imagens, para o autor, ocorrem no interior da fantasia em uma oposição de duas imagens fantasmáticas. A experiência que aqui denominamos como negativa diz respeito ao encontro gerado entre a realidade e a fantasmática em situação de oposição entre estas. Um dos exemplos dados por Barthes (2003, p. 10) para ilustrar a oposição interna de contra-imagens fantasmáticas é "ficar fechado por toda eternidade com pessoas desagradáveis que estão em nosso lado no restaurante". Já na experiência negativa do Viver-Junto-idiorrítmico, a realidade da vida vivida, do cotidiano, adentra a fantasia escancarando as engrenagens por trás das atitudes de indivíduos.

Não é somente a presença desagradável que se faz realidade, mas os preconceitos e as estruturas de opressão e injustiça social que como em um olhar pela lupa são vistas maximizadas. Ao encararem-se estas questões ou ser por elas revelado, a fantasia rompesse e junto a este rompimento revela as narrativas que constroem a realidade concreta. A epokhé "entendida, aqui, como 'suspensão provisória' das ordens, leis, cominações, arrogâncias, terrorismos, intimações, dogmatismos entre seus membros" (FABBRINI, 2018, p. 120), essencial para a fantasmática barthesiana não sobrevive integralmente à violência, ou 
crueldade (em seu sentido artaudiano) do encontro com os corpos performáticos.

A temática do espetáculo encontra sintonia com a emergência da problemática da "alteridade" na pós-modernidade, na qual questões como diferenças de subjetividade, questões de gênero e sexualidade, relações entre raça e classe tomaram centralidade na cena. Os estudos feministas ao longo da segunda metade do século XX e das primeiras décadas do século XXI têm colaborado para uma revisão histórica e um deslocamento de paradigmas sociais. Artistas desconhecidas estão sendo colocadas em evidência e tendo suas obras e biografias revisitadas, novas esferas de discussão estão mediando pesquisas acadêmicas e produções artísticas, como é o caso dos estudos interseccionais.

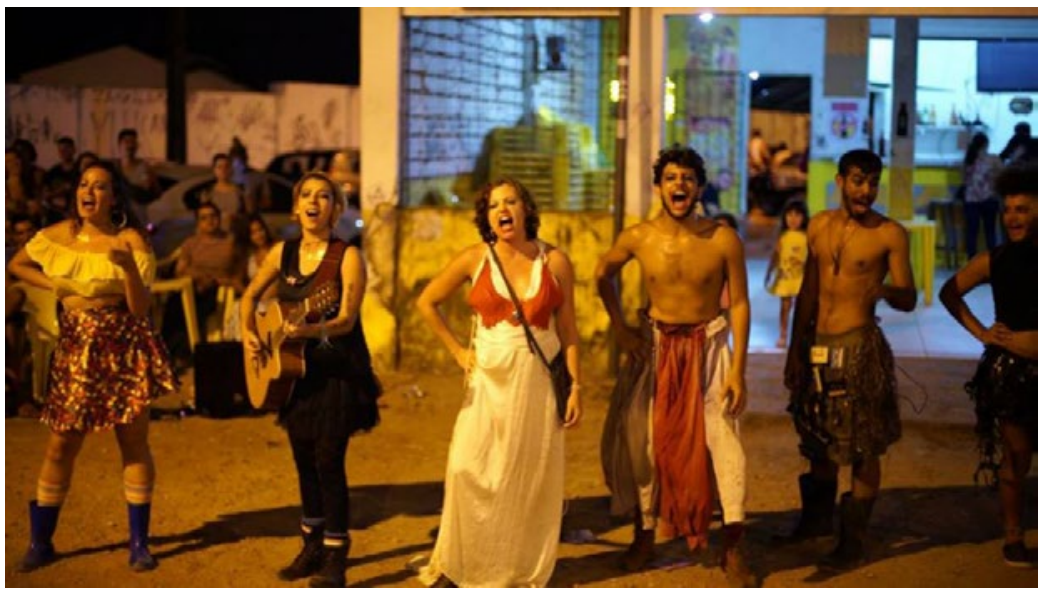

Figura 3: Projeto Corpos de Saia - Espetáculo No mundo da rua

Fonte: Acervo Projeto Corpos de Saia

A falta de uma análise com tendência à universalidade acerca de uma problemática social, por parte da estrutura dramático-espetacular da peça é contraposta a um discurso que é localizado espacial e temporalmente. Os corpos que ali estão tecendo relações, cantando, dançando, sorrindo e propondo poesias fazem eclodir no público a necessidade de um posicio- 
namento ético imediato para com aqueles sujeitos. Não é dado o espaço da reflexão e da abstração, mas é solicitado um gesto afetivo imediato dos que ali se encontram. A urgência da vida se faz presente como texto espetacular e como exigência para a fruição da obra.

No Mundo da Rua é uma experiência não integral do ViverJunto-idiorrítmico, uma construção relacional da obra teatral, uma heterotopia que se mantêm na resistência à possibilidade de uma neutralidade ou de certa brandura fictícia, por vezes encontrada em obras artísticas que dialogam com tais teorias ou mesmo na própria proposta conceitual. A experiência estritamente positiva de um Viver-Junto-idiorrítmico em uma sociedade com problemas profundos de desigualdade social, racismo, LGBTfobia, misoginia etc. far-se-ia possível apenas em um grupo de iguais. A diferença se coloca como provocação e espelho no qual se refletem as monstruosidades do público (seu eu estruturado na intolerância). Essa fantasmagoria pensada por Barthes é impossível no interior de uma sociedade na qual grupos minoritários têm medo de ocupar as ruas, visto que sua integridade física está a todo o momento, ameaçada. A fantasia não sobrevive à presença de corpos que devido aos seus marcadores sociais de raça, gênero e classe revelam um estado de opressão e injustiça social. O espetáculo não apresenta a ingenuidade da crença em um estado de paz, afinal, como disse Marcelino Freire: a paz é coisa de rico, a paz é branca. O espetáculo traça relações doces, relações afetuosas para, em seguida, apontar a crueldade presente naquele espaço, mas mascarada de socialidade. Ao teatro contemporâneo interessa o que compreendemos aqui como experiência negativa do Viver-Junto-idiorrítmico, pois para além de propor uma breve prática de outra possível realidade, ele nos expõe cruelmente em nossos preconceitos e desvela, a partir da iluminação das narrativas sociais, as quais são potencializadas pela presença e performatividade de corpos com marcadores sociais de diferenças, a ficcionalidade da vida vivida. 


\section{REFERÊNCIAS}

AMARAL, I.; MELLO, A. Prefeitura de BH proíbe manifestação política de artistas na Virada Cultural. Estado de Minas. Belo Horizonte, 05 Jul 2016. Disponível em: https://www.em.com. br/app/noticia/politica/2016/07/05/interna_politica,780238/ prefeitura-proibe-manifestacao-politica-de-artistas-na-viradacultural.shtml. Acesso em: 01 nov. 2019.

BARROS, José A. Os Falanstérios e a crítica da sociedade industrial: revisitando Charles Fourier. Mediações, Londrina, v. 16, n. 1, p. 239-255, Jan./Jun., 2011.

BARTHES, R. Como viver junto: simulações romanescas de alguns espaços cotidianos. São Paulo: Martins Fontes, 2003.

. O prazer do texto. São Paulo: Perspectiva, 1987.

BOURRIAUD, N. Estética relacional. São Paulo: Martins Fontes, 2009.

FABBRINI, R. Arte pós utópica: heterotopia e comunidade. In VACCARI, Ulisses R. (Org). Arte e estética. São Paulo: Cultura Acadêmica, 2018.

- Estética e transgressão: da arte radical à arte radicante. Artelogie (Online), v. 8, p. 1-15, 2016.

. Fronteiras entre arte e vida. ArteFilosofia, Ouro Preto, n. 17, p. 41-60, Dez., 2014.

FOGLIATTO, D. Artistas de rua criticam minuta de decreto da prefeitura que regulamenta atividade. Sul21. Porto Alegre, 19 ago. 2015. Disponível em: https://www.sul21.com.br/ cidades/2015/08/artistas-de-rua-criticam-minuta-de-decretoda-prefeitura-que-regulamenta-atividade/. Acesso em 01 nov. 2019.

FOUCAULT, M. O corpo utópico, as heterotopias. São Paulo: N-1 Edições, 2013. 
HUYSSEN, A. Mapeando o pós-moderno. In HOLLANDA, Heloisa B (Org). Pós-modernismo e política. Rio de Janeiro: Rocco, 1992. RANCIÈRE, J. A estética como política. Devires, Belo Horizonte, v. 7, n. 2, p. 14-36, Jul./Dez., 2010.

Fontes, 2012.

O espectador emancipado. São Paulo: Martins 